\title{
The Implementation of English in Higher education in the context of ASEAN Economic Community (AEC) in an International Accounting Department
}

\author{
Wulan Fauzanna \\ English Department, Andalas University \\ Padang, Indonesia \\ wulanfauzanna@gmail.com
}

\begin{abstract}
In response to the need to use English in the context of the ASEAN Economic Community (AEC), the Indonesian Ministry of Research and Technology and Higher Education has required that universities offer a bilingual curriculum in selected disciplines (Farmita, 2014) for the economic benefits for students and institutions (Shohamy, 2014). It is believed that English as a medium of instruction (EMI) would support internationalization of the higher education sector and would be advantages in competition within the region. Implementing a bilingual curriculum is especially complex in Indonesia, where a majority of the public speaks a local language as their first language and must master Indonesian to participate fully in the public realm. This study aims to evaluate an EMI program in an international Accounting Department. Document analysis and survey are conducted to reveal students' perspectives on the implementation of the program. This study finds that the program has been very supportive for students, regarding the bilingual activity and enough exposure to English. The limitation is in the support from the university regarding the facilities, improvement in teaching and learning methods.This studywill serve as the basis for more effective language teaching and program implementation in the context of AEC.
\end{abstract}

Keywords-EMI, Implementation, Accounting, AEC

\section{INTRODUCTION}

Globalization has accelerated the growing use of English and increased demand for English, especially in higher education (Barnard, 2014).The implementation of English as Medium of Instruction or EMI in Asia has been influenced by the success of the EMI in Europe through the Bologna Process (Kirkpatrick, 2014). In Europe, the EMI is intended to promote the internationalization of university through study abroad program and overseas partnership (Doiz, Lagabaster, and Sierra, 2013). The EMI has managed to increase students competitiveness to be a success in the career prospects, postgraduate study abroad and a scholarship application (Han and Singh, 2014; Doiz, Lagabaster and Sierra, 2013).

Currently, universities in the world have created bilingual programs to attract local and international students. The bilingual program is a way to help students succeed in their learning (Huang,2015). Universities in Asia implemented a bilingual class, applying national and foreign language, mainly English. Each language has a particular function to support academic purposes (Kirkpatrick, 2011). EMI has been implemented to address global challenges with a high need for English language skills to compete in getting jobs in various places in ASEAN countries (Araminta and Halimi, 2015). In response to this situation, the Ministry of Research and Technology and Higher Education (Ristekdikti) has instructed the implementation of dual language in Higher Education because of high demand for EMI in university (Dewi, 2017). The content subject is delivered using English and national language (Sinaga, 2016).

EMI implementation in Indonesia commences in several universities with the aim of achieving 'world-class university.' Meanwhile, the challenge that arises in a multilingual Indonesian community is the negotiation between the English language and the national and local languages, such as Indonesian (Kirkpatrick, 2012, 2014). The Indonesian government has established the Indonesian language as the national language (Paauw, 2009). However, English is also an important language, Farmita (2014) reports that the government proclaims that by 2015 all universities in Indonesia are required to carry out bilingual lectures. This policy is issued to welcome the establishment of the ASEAN Economic Community (AEC), which begins in late 2015.

As part of the ASEAN community, several Indonesian universities become a member of the Australian University Network (AUN), an organization which is a collaboration of universities in ASEAN countries to receive a required standard to compete globally. The government has stated implementing bilingual education at the University. Minister of Research and Technology, M.Nasir stated the importance of preparing college students for facing AEC, as she said that "If in the era of AEC, our education system has to produce competitive human resources. In the competition, the winners are those who have capabilities.

The implications of EMI in universities in ASEAN appears to gain economic benefits such as getting better jobs (Hashim, Leong and Pich, 2014). Government policies on bilingual education in 2015 have been a challenge for Indonesian universities, because of several limitations, such as the lack of English proficiency of lecturers (Kirkpatrick, 2011, 2014). Meanwhile, the English proficiency index of Indonesian citizens is ranked 3rd in ASEAN (EF EPI).

In implementing EMI, the university must have a strategy, such as applying the international curriculum, collaborative programs with universities abroad and the importance of institutional websites' role in providing information to parties from 
overseas in English (Soejatminah, 2009, Barnard, 2014). Also, it trains students' English skills through an extracurricular activity, such as English debate program (Husnawadi \& Syamsudarni, 2016).

Andalas University which famous as UNAND is one of the state universities in Indonesia located in Padang, West Sumatra. Padang is a coastal suburb with access to foreign countries through Minangkabau international airport. UNAND has responded to the market needs of globalization by opening international classes since 1999 and English classes were started in 2014 . The program aims to increase student skills by improving English language proficiency. All courses are delivered in English.The university's motivation is to achieve the international standard. The Program still has several challenges in its implementation regarding college location difference, public education level, and income. Therefore, the use of English at university still has some points to study by evaluating the implementation of EMI in an International Accounting Program at UNAND.

\section{THEORETICAL FRAMEWORK}

A. The internationalization of Higher Education

The process of globalization has affected all sectors of life; economic, political, sociological and educational. Globalization has evolved along with the development of information technology. The technology has made the changes in life, including the spread of English and influenced the English teaching (Manara, 2014). Jenkins (2014) discusses that the globalization of higher education means that English is the primary language of instruction. It means that English become global and attract the competition to achieve a world-class university.

English has become a Lingua Franca in the era of globalization and has been used in local and world settings, and it has been widely agreed upon by speakers. English in education must also adapt to local needs (Canagararajah, 2006 in Manara, 2014). Education should be a concern in teaching English because the use of language in the teaching in this globalization era should contain the values of local languages and cultures that are implemented in English teaching. Soejatminah (2009) reported that there are seven criteria of an international university (Soejatminah, 2009), including:

1. Website in English

2. ICT, such as e-learning, forum, network

3. Acknowledgment of internationalization

4. Website for international matters, such as International engagement

5. Internationalization of the student body, such as student exchanges, student mobility

6. Internationalization of the academic staff/faculty collaboration, such as Academic recharging program, research collaboration and sandwich program.

7. Internationalization of the curriculum, such as Sandwich Program. Twinning and Double Degree. Furthermore, from the seven criteria above, another criterion has been added, as the support to the program,

8. Students Extracurricular activities

EMI allows the Code-switching between local or national language and Foreign language (Kirkpatrick, 2011).Meanwhile, the challenge that arises in a multilingual Indonesian community is the negotiation between the English language and the national and local languages, such as Indonesian (Kirkpatrick, 2012, 2014).The international program uses English textbook. As the result of the program has been designed for internationalization, (Menendez, Grande, Sanchez, Minano, 2017) reported that EMI students are more successful, motivated than non-EMI students. EMI Students have better learning strategy, time study management and have bigger efforts. They have more efforts because of learning in a foreign language and have more strategies to be a success. Araminta and Halimi (2015) discuss the limitation of the English skills of the Indonesian workers working in the multinational company, are grammar and pronunciation.

\section{B. EMI in Higher education in Indonesia}

EMI in Indonesia is a way to improve the lecturers and students' English proficiency. Also, it aims for improvement in publications and presenting the results of research in English. Language policy in the field of education often does not pay attention to readiness and implementation in society, which means that the facts about the English language eloquence of the community in welcoming the EMI program often do not meet the EMI application requirements in the university. However, policies have been taken to implement EMI (Diallo \& Liddicoat, 2014). Araminta and Halimi (2015) reported that from the needs analysis carried out at the Faculty of Engineering at the University of Indonesia, it was concluded that students need a program which can develop their English skills not to teach them English.

EMI is a government policy towards the use of language in higher education. As an effort to create an international level of education, EMI is an attempt to "enhancing students' English abilities, promoting the internationalization of the local education system," (Han \& Singh, 2014). Kirkpatrick (2011) reports that EMI programs in Southeast Asian and Asian countries are rigorous because of the needs of good lecturers and student competencies. This limitation was also indicated by The British Council (2015). In light of this constraint, Han and Singh (2014) stated that EMI emphasizes the use of strategies to achieve a quality 
learning system by increasing the skills of teachers and students, the curriculum and programs offered by the university to improve the capacity of lecturers and students.

\section{Indonesian Higher Education in AEC}

In the establishment of The ASEAN Organization, formed in 1967, aims to unite Southeast Asian countries to confront communism. The country consists of Indonesia, Malaysia, Philippines, Singapore, and Thailand. Next, five other nations have joined namely Brunei, Vietnam, Laos, and Myanmar. Followed by Cambodia and the last country to join Timor Leste.

At the time of the founding of ASEAN, there was no draft of the primary language in the ASEAN community; although three countries use almost the same languages as Indonesia, Malaysia, and Singapore (Kirkpatrick, 2012). Recently, English has become Lingua Franca for ASEAN citizens based on ASEAN charter in 2009. It states that "the working language of ASEAN shall be English" that English is the language used as the primary language in ASEAN operational. The second article mentions that speakers should still appreciate language differences from the ASEAN community.

The ASEAN Economic Community (AEC) is a challenge for the implementation of education in universities. It is started on December 31st, 2015, for the free of capital, goods, service, and people (Hashim, Leong, and Pitch, 2014). University must provide lecturers, students, and academic staff with capacity for the program and the manager who can manage an international institution. The AEC aims to unite the economies of ASEAN countries by the vision of ASEAN in 2020.

Language policy in higher education has been implemented in several ASEAN countries, such as Malaysia has implemented the teaching of science and math uses English. Vietnam, through the Vietnam goal 2020 is aimed to prepare college students to speak English. Cambodia uses English mainly for communication. The trend among ASEAN countries shows the promotion of national language and English in higher education.

\section{International Accounting Program at UNAND}

In the Indonesian context, language selection in education requires attention. Indonesia is a multicultural country with diverse cultural and linguistic differences. Bahasa Indonesia has been chosen as a language of unity and is used as a language of instruction in the field of education. English is a Foreign Language in Indonesia. Meanwhile, at Higher education, English is made into one of the compulsory subjects under the name of the General Course (MKDU) taught in the first year of university.

Universitas Andalas (UNAND) as an example of a university that implements English as a medium of instruction. UNAND has international classes and English classes. In this class, the content subject is taught with English medium. Five study programs run Kelas Berbahasa Inggris (KBI) and three research programs in Faculty of Economics who run International class. International classes in the Faculty of Economics have been started since 2009, and English classes begin in 2014 in five Nursing, Chemical, Biology, Pharmaceutical and Industrial Engineering, with TOEFL 450 as requirements. The program prepares students with skills, content subject and also English skills. It is expected that students can compete better in getting a job. The program also includes student exchange and student mobility abroad with universities in cooperation with an International accounting program, such as several universities in Malaysia.

\section{E. Motivation}

Dörnyei (2016) states that motivation is a 'goal' or 'target' in achieving a particular goal. Motivation is a variety of efforts in achieving individual goals. Research in the field of motivation for second language learning can be used to know how to learn and student performance. Through the study of motivation, it can be seen why someone is more successful than others, why motivation is related to success and failure and how motivation can help educators to make learning condition better.

\section{METHOD}

This study is expected to evaluate the programs that have been implemented in an international class. This study is aimed to learn the implementation of EMI program and review the use of language in the process of learning and teaching through students' motivation to study in EMI program. This research applies a qualitative and quantitative. The available documents related to the program are reviewed to get an understanding on the implementation of the program. The participants of this research are second and third-year students in International accounting program to participate in the survey.54 students are involved in filling in the surveys. The students are Indonesian speakers and have experienced learning English for more than 10 years. Students are interviewed to be accepted in the program. The questionnaires were delivered in a class students took with the permission of the lecturer. All of the questionnaire are returned and used as the data. As the documents available are very limited, the head of the Department was interviewed to get a thorough understanding of the program. 
Data collection methods will be applied as the following:

A. Document Analysis

The research will be conducted by looking at the related papers on the implementation of EMI in the International Accounting Program. This method is used because it will be able to evaluate the programs that have been implemented through the written information and interview with the head of the Accounting Department International Program and from the documents available in paper and the websites.

\section{B. Survey}

The survey will be conducted to the students; Some questions will be asked and answered with Likert scale.There 6 categories from Strongly disagree to strongly agree. That is a statement that must be answered by looking at the tendency of respondent choice. This method is implemented to see students' perceptions of EMI implementation in their study program and study students' motivation in EMI class related to AEC. The survey was developed from Motivation questionnaire (You \& Dörnyei, 2016; You, Dörnyei, Z., \& Csizér, K., 2016) and a survey of students’ perspectives on EMI (Wei, Feng, and Ma, 2017). The data from the survey is interpreted using statistic analysis.

\section{FINDING AND DISCUSSION}

\section{A. Institutional motivation in EMI}

In studying the eight criteria of internationalization in university, the documents are insufficient, such as the guidelines of the program and the website provided has limited information. The website provides little information and is written in Indonesian. The information of the programs and events can be found on the faculty website. The guidebook which contains information about the curriculum and other relevant information is not available. The program also has similar administration with the monolingual class which is conducted in Indonesian. The head of the Department was interviewed to get a thorough understanding of the program.

From the criteria of an international university (Soejatminah, 2009), the accounting department has not yet supported by the university, especially, in facilitating website in English, ICT, e-learning or forum. The international program such as the sandwich program and double degree is also not available.

Teaching and learning are conducted conventionally, through face to face interaction. Only a few teaching staffs are reported to do e-learning, and the system is not institutionally used for the whole lecturers, only by several lecturers. However, the program offers exposure to English; students write their thesis in English, Seminar presentation in English and students have to obtain a certain TOEFL scores to graduate. The program also invites experts from other countries to give the lecture for the lecturers and students to build English speaking atmosphere.

The acknowledgment of the internationalization has been stated in the university statement; however, the program does not explicitly mention the internationalization in its website. Though the program has joined the ASEAN University Network Quality Assurance (AUN QA) which allows the improvement in the quality of teaching and learning, it was not found on the department website. Joining accredited body for internationalization is a way to apply international standard (Soejatminah, 2009).

The program supports the internationalization of students and lecturers, through several programs, such as; student exchanges, student mobility, the internationalization is mainly among universities in ASEAN countries. The university supports through the grants are provided by students and lecturers for a short visit to universities in foreign countries. Stroupe and Kimura (2015) reported that the challenges of ASEAN Economic community are in the use of English as an international language. It needs improvement in the English language proficiency of the teachers, students, and government officials. This capability supports the success of the implementation of AEC in the region. The British Council (2015) reports that EMI's engagement in Indonesia is constrained by low-competence teaching staff to teach the subjects they receive. The study shows that the program has human resources with the relevant academic background, as many of the teaching staffs have an academic qualification from universities abroad and enough assistance for teaching staffs through Academic recharging program. In addition, most students have learned English for more than ten years and have extra classes for studying English.

To support the exposure to English is the extracurricular activities that more than half of the students join. Many students Join AIESEC, an international organization for youth leadership development. The activities involve students' exchange and community development program. One of the programs was a Global Village, which invites international students for an internship in Padang through the AIESEC organization.The limitation of conducting the program is in the support for facilities for an internationalization because of the limited funding allocated by the university. Thus, it needs special attention by the policymakers in the university. The institution support is very significant for the success of the program (Lawrence, Ofra \&Weinberg, 2017) 


\section{B. Students' Motivation of studying in EMI}

Most universities in Asia face the challenges by the multitude of local languages. The use of local language in the community and the lack of English environment becomes an obstacle factor in the EMI application. For example, Hong Kong's residents are required to master English and Chinese. Most universities set bilingual and three-language policies (Kirkpatrick, 2011).

The findings show that Students agree (67\%) of the bilingualism in the teaching and learning process. As textbooks are in English, the lectures are conducted in English and Indonesian. The extracurricular activities support students engagement with the international community. Most of the Students (90\%) agree on the benefits of the bilingual class. They believe that through studying in bilingual class, they can improve their English, they can prepare themselves for future study in English speaking countries and increase competitiveness in finding the jobs. Students have L2 learning experience. The support provided by the program has helped them improved their capabilities.

\section{Students' motivation to study in EMI program to involve in AEC}

ASEAN Economic Community aims to unite the economies of ASEAN countries by the vision of ASEAN in 2020. Furthermore, ASEAN is an economic strength that integrates and strengthens ASEAN organizations (ASEAN Secretariat, 2008).Students believe that AEC is a challenge they have to face related to the job competitiveness. English is essential to be acquired because it can increase the university ranking, it helps them to communicate with people in ASEAN, it improves the competitiveness among other citizens in ASEAN, and it is one of the requirements for the success in AEC. Students get economic benefits from acquiring English.

Students' response toward the AEC is positive. Students see it as a challenge, but they also think that they have to improve their capability to succeed.Students have the motivation to learn English because of the benefits they will get from the AEC, such as the economic benefits, the competition in job hunting, preparation for further study and the communication with English speakers. Students have L2 motivation, toward the image of themselves. They understand the benefits of the program. English can grow Indonesian people's identity through the communication, sharing knowledge and building international economy (Dewi, 2017). Thus, English becomes compulsory in higher education to face the challenge in AEC.

In light with this, Gajaseni (2016) reported that after 2015 trend in Higher education emphasis on the following steps: 1.Internationalization, 2.Quality assurance 3, ICT for higher education 4. financial support and 5. development of higher education. Thus, higher education institution need to reform their policies and apply strategic management to improve the quality of the graduates. AEC needs support from higher education sector in order to improve the education quality in the region. The ASEAN ministers have agreed on the five years work plan to have cooperation for community building.The UNAND students from the international program has been prepared to face the challenge. They have been aware of the competition in AEC and prepare themselves through learning English and Accounting.

\section{CONCLUSION AND SUGGESTION}

The ASEAN Economic Community is a challenge for the implementation of education in universities in ASEAN. The university must provide good response toward the internationalization of the program. The university should support the students, lecturers and academic staff for English exposure and have the international standard in implementing the program. The extracurricular activities and students mobility program should be continued as the primary program in the department.

\section{References}

Araminta, L,D.W \& Halimi, S,S (2015). ASEAN Economic Community 2015: Needs analysis of University of Indonesia's Engineering students. Indonesian Journal of Applied Linguistics, vol.5 no.1, pp.11-18,2015.

ASEAN Secretariat.Towards ASEAN Economi Community 2015. Monitoring ASEAN Economic integration. Jakarta: ASEAN Secretariat.2017.

Barnard, R. English Medium Instructions in Asian university: Some concerns and suggested approach to dual medium instruction. Indonesian journal of Applied Linguistics. Vol 4, no.1, pp. 10-21.2014.

British Council. Minutes of Meeting. English and Higher Education in Indonesia. Jakarta. March 12, 2015.Retrieved from https://www.britishcouncil.id/ sites/default/files/plenary_session_2.pdfcover_option_3_final_web.pdf

Dewi, A. English as Medium of Instruction in Indonesian Higher education: A study of Lecturers' perceptions. In Fenton-Smith et al (eds) English Medium Instruction in Higher Education in Asia Pacific, Multilingual Education ,21, 2017. DOI 10.1007/978-3-3319-51976-0_13.

Diallo, I \& Liddicoat, A. Planning Language teaching: An argument of the place of pedagogy in language policy and planning. International journal of Pedagogies and Planning. Vol. 9 no.2.2014.

Doiz A, Lagabaster, B \& Sierra, J.MEnglish as L3 at a Bilingual University in the Basque Country, Spain.in Aintzane Doi, David Lagabaster and Juan Manuel Sierra (eds). English-medium instruction at universities: Global Challenges. Bristol: Multilingual Matters.2013.

EF EPI. English Proficiency Index 2015. 2015. Retrieved from http://www.ef.co.id/epi/

Farmita, R.Sambut MEA, Tahun depan perkuliahan wajib dual language.29 November, $2014 . \quad$ retrieved from https://m.tempo.co/read/news/2015/11/29/079723145/sambut-mea-tahun-depan-perkuliahan-wajib-dual-language

Gajaseni, N. Trends and Challenges in ASEAN Higher Education towards ASEAN Integration.In Azirah Hashim (ed), The ASEAN higher Education Forum(AHEF) 2015. Kuala Lumpur: ASIA-Europe Institute, University of Malaya.2015.

Han, J, Singh, M. Internationalizing Education through English MEdium Instruction. Key Theoretic-Pedagogical Ideas. Research Project report. Sydney: University of Western Sydney.2014. 
Hashim,A, Leong, Y,C, Pich, P,T. (2014). English in Higher Education in Cambodia. World Englishes. Vol.4, pp.498-511.

Husnawadi \& Syamsudarni. The role of English Debating Tournament in the face of the ASEAN Economi Community (AEC). Dinamika Ilmu, Vol 16, no.1.2016.

Jenkins, J .English as a Lingua Franca in the international university.The politics of academic English language policy. Abingdon,UK: Routledge.2014.

Kirkpatrick, A. EMI in Asian Education (from primary to tertiary) : Implications for local language and local scholarship. Applied Linguistics review 2.2011.

Kirkpatrick, A. English in ASEAN: implications for regional multilingualism. Journal of Multilingual and Multicultural development. Vol. 33, no. 4, pp. 331344.2012. DOI: 10.1080/01434632.2012.661433.

Kirkpatrick, A . English as a medium of instruction in East and Southeast Asian universities. In Murray, N \& Scarino, A (eds). Dynamic Ecologies. Springer.2014.

Kirkpatrick, A . The language (s) of HE: EMI and /or ELF and /or multilingualism?.The Asian journal of Applied Linguistics.Vol.1 no. 1, pp 1-15.2014.

Kirkpatrick, A.English as a medium of Instruction in Asian Education (from Primary to tertiary): Implications for local languages and local scholarship. Applied Linguistics Review, 2, pp. 99-120.2011. from DOI:10.1515/9783110239331.99

Manara, C.“That's what worries me" : Tensions in English language education in Today's Indonesia. International Journal of innovation in English Language. Vol.3 no 1.2014.

Menendez, M,J,R,M, Grande,E,U,Sanchez, P,P \& Minano, M,M,C.Motivation and Learning Strategies in accounting: Are there differences in English as a medium of Instruction (EMI) versus non-EMI students? . Revista de Contabilidad-Spanish Accounting review. 2017. http://dx.doi.org/10.1016/j.rcsar.2017.04.002.

Paauw, S (2009). One land, one nation, one language: An analysis of Indonesia's national language policy. In H Lehrent Le houillier and A.B Fine (eds).University of Rochester working papers in the language sciences. Vol 5 no.1. pp. 2-16.2009.

Shohamy, E. A critical Perspective on the use of English as a medium of instruction at Universities. In Doiz, A, Lasagabaster, D \& Sierra, M.J (eds), EnglishMedium of instruction at universities. Global Challenges(pp.196-210). 2014.Bristol: Multilingual Matters. Retrieved from books.google.co.id.

Soejatminah,S. Internationalization of Indonesian higher education: A study from the periphery. Asian Social Science. Vol 5 no. 9.2009.

Stroupe, R \& Kimura, K. Opportunities and Challenges Across ASEAN: Looking Ahead to the ASEAN economic Community.In Richmond Stroupe and Kelly Kimura (eds). ASEAN Integration and the role of English Language http://dx/doi.org/10.5746/LEiA/ASEAN_Integ_ELT

Wei, R, Feng, Jieyun, Ma, Qin. College students' perspectives on English Medium instruction and their English learning motivational intensity.inEnglish-Medium instruction in Chinese Universities: Perspectives, discourse and evaluation. Zhao, J,Dixon,L,J (eds). New York: Routledge. 2017.

You, C;Dörnyei, Z.Language learning Motivation in China: Result of a large-scale Stratified survey. Applied Linguistics. 37/4. pp.495-519. 2016. 